\title{
Contribution of legumes to the availability of soil nitrogen and its uptake by wheat in Mediterranean environments of central Chile
}

\author{
Soledad Espinoza ${ }^{1}$, Carlos Ovalle ${ }^{1}$, Erick Zagal², Iván Matus ${ }^{1}$, and Alejandro del Pozo ${ }^{3 *}$
}

The absorption and partitioning of $\mathrm{N}$ is determined by its availability and demand during the various phenological stages of the crop. In two experiments conducted in rainfed areas of the Mediterranean climate region of central Chile, legume-wheat (Triticum aestivum L.) rotations were compared to oat (Avena sativa L.)-wheat systems (with and without applications of $\mathrm{N}$ fertilizer). The objective was to assess the contribution of legumes to the availability of soil $\mathrm{N}$ and $\mathrm{N}$ uptake by the wheat crop following grain legumes. $\mathrm{N}$ mineralization and uptake, $\mathrm{N}$ use efficiency (NUE), and $\mathrm{N}$ uptake efficiency $\left(\mathrm{NU}_{\mathrm{p}} \mathrm{E}\right)$ by wheat were evaluated at different phenological stages in 2010. Synchronization existed between accumulated soil $\mathrm{N}$ mineralization and $\mathrm{N}$ uptake by the wheat. $\mathrm{N}$ uptake by wheat was higher in Experiment II (Andean foothill) than in Experiment I (interior dryland). Grain yields after legumes ranged 60-110\% and 72-103\% of yields in the fertilized cereal rotation (oat-wheat) in Experiments I and II, respectively. There was high correlation between soil $\mathrm{N}$ availability $v s$. grain yield $\left(\mathrm{R}^{2}=0.84\right.$ and 0.64$)$ and $\mathrm{N}$ uptake $v s$. grain yield $\left(\mathrm{R}^{2}=0.55\right.$ and 0.64$)$ for Experiments I and II, respectively. Rotations with lupine (Lupinus spp.) and field peas (Pisum sativum L.) showed high NUE and $\mathrm{NU}_{\mathrm{p}} \mathrm{E}$ in Experiment I, and Experiment II in pea. The lowest NUE was after oats with $\mathrm{N}$ fertilizers. It is concluded that wheat cultivated in both agro-ecological areas after grain legumes or green manure was more efficient in $\mathrm{N}$ uptake and use than cereal, especially when the latter was fertilized.

Key words: Alfisol, Andisol, crop rotation, field peas, lupins, N uptake, oat, Triticum aestivum, vetch.

\section{INTRODUCTION}

Grain yield and quality in wheat (Triticum aestivum L.) are closely related to the uptake and use of $\mathrm{N}$ (Guarda et al., 2004). In rainfed areas of the Mediterranean climatic region of central Chile, wheat is generally cropped in rotation with oats, or after 3-5 yr of naturalized pastures, and it has a strong reliance upon $\mathrm{N}$ fertilizer to maintain productivity, which increases the costs of production by approximately 25\% (Mellado, 2007). While cereal yield potential is commonly constrained by water deficit at the end of spring in these environments (del Pozo et al., 2012), grain quality tends to be higher than under irrigated conditions (Castillo et al., 2012). Thus the challenge in rainfed areas is to increase wheat profitability by reducing production costs but without losing grain yield and quality, and also to develop more sustainable production systems.

\footnotetext{
${ }^{1}$ Instituto de Investigaciones Agropecuarias, INIA Quilamapu, Av. Vicente Méndez 515, Chillán, Chile.

${ }^{2}$ Universidad de Concepción, Facultad de Agronomía, Av. Vicente Méndez 595, Chillán, Chile.

${ }^{3}$ Universidad de Talca, Facultad de Ciencias Agrarias, Av. Lircay s/n, Talca, Chile. "Corresponding author (adelpozo@utalca.cl).

Received: 7 May 2014.

Accepted: 20 November 2014.
}

doi: $10.4067 /$ S0718-58392015000100016
Including legumes in crop rotation is a potential way of increasing the available $\mathrm{N}$ supply for cereals at low cost (Angus et al., 2006; Espinoza et al., 2012). The inclusion of legumes in a cropping sequence can also improve soil quality, porosity, and structure (Rochester et al., 2001; McCallum et al., 2004) and influence specific microorganism populations in the rhizosphere (Kirkegaard et al., 2008; Osborne et al., 2010) for the benefit of following crops. The combined impact of all these factors is that post-legume cereal yields are often reported to be $40-80 \%$ greater than that achieved in cereal without $\mathrm{N}$ fertilizer, representing an additional 450-1000 kg of additional grain per hectare across a range of environments (Hayat and Ali, 2010; Seymour et al., 2012).

In a cropping sequence, crop residues returned to soils are the main source for $\mathrm{N}$ mineralization and available $\mathrm{N}$ supply for a cereal crop. The $\mathrm{N}$ mineralization rate is influenced by numerous factors where the type and amount of incorporated crop residues as well as soil and environmental conditions are of great importance (Giacomini et al., 2007). In the Mediterranean region of central Chile, wheat is cultivated in the eastern part of the coastal mountain range (interior dryland) and in the Andean foothills. In the former area, soils are of granitic origin with low soil organic matter (SOM) and reduced water holding capacity, and as a consequence cereals are usually exposed to a severe water stress during grain 
filling (del Pozo et al., 2012). By contrast, in the Andean foothill soils are of volcanic origin, with higher SOM and soil water availability for crops, and therefore the yield potential for cereal crops is much higher than in the interior dryland. There is little information on the $\mathrm{N}$ mineralization rate in the legume-wheat rotation and how it is related to the $\mathrm{N}$ uptake by the wheat crop in these two contrasting environmental conditions. In addition, this study should contribute to a better understanding of the dynamics of legumes residues in rainfed Mediterranean agriculture, and their contribution to wheat $\mathrm{N}$ nutrition.

Nitrogen uptake and partitioning is largely determined by the availability of this nutrient in the soil and by the demand of the crop in its different phenological stages (Campbell and De Jong, 2000). In wheat the $\mathrm{N}$ assimilated prior to anthesis can be as high as $60-80 \%$ of the total $\mathrm{N}$ measured at maturity (Sun et al., 2012). However, these percentages vary depending on the wheat cultivars and environmental factors like temperature, humidity, water availability and $\mathrm{N}$ content in the soil (Sun et al., 2012). Under high soil fertility conditions, $\mathrm{N}$ uptake in the post-anthesis phase is important as it has been positively correlated to protein content of the grain and the $\mathrm{N}$ index at harvest (Sarandón et al., 1997).

In a previous paper (Espinoza et al., 2012) it was shown that grain legumes fixed large amounts of $\mathrm{N}_{2}$ and wheat yields following grain legumes were $70-110 \%$ of the yields achieved by $\mathrm{N}$-fertilized wheat crops grown following oats. The objective of this study was to assess the contribution of legumes to the availability of soil $\mathrm{N}$ and the $\mathrm{N}$ uptake by the wheat crop following grain legumes in two rainfed areas of the Mediterranean climate region of central Chile.

\section{MATERIALS AND METHODS}

\section{Site description and experiment management}

Two experiments of cropping sequences were undertaken at two locations in central Chile where legume-wheat rotations were compared to oat-wheat systems with and without applications of $\mathrm{N}$ fertilizer. Experiment I was conducted at the Experimental Center of CauquenesINIA (35 $58^{\prime} \mathrm{S}, 72^{\circ} 17^{\prime} \mathrm{W} ; 140 \mathrm{~m}$ a.s.l.), in the sub-humid Mediterranean zone in the interior dryland in the eastern part of the Chilean Andean range. The soil was a granitic classified as Ultic Palexeralfs. Soil pH (1:2.5 in water, 0-20 $\mathrm{cm}$ ) was 7.0 , the organic matter content was $1.6 \%$ and the concentrations of available mineral N, P, and $\mathrm{K}$ in the top 20 $\mathrm{cm}$ were $2.3,12$, and $185 \mathrm{mg} \mathrm{kg}^{-1}$, respectively (Espinoza et al., 2012) according to established methodologies in Sadzawka et al. (2006). Experiment II was conducted on a farmer's field in Yungay County $\left(37^{\circ} 10^{\prime} \mathrm{S}, 71^{\circ} 58^{\prime}\right.$ W; $297 \mathrm{~m}$ a.s.1.), in the humid Mediterranean zone of the Andean foothills. The volcanic origin soil was classified as Typic Haploxerands. Soil pH (1:5 in water, 0-20 cm) was 5.8 , the organic matter content was $15 \%$ and the concentrations of available mineral $\mathrm{N}, \mathrm{P}$, and $\mathrm{K}(0-20 \mathrm{~cm})$ were 4,9 , and $49 \mathrm{mg} \mathrm{kg}^{-1}$, respectively. Mean monthly temperatures $\left({ }^{\circ} \mathrm{C}\right)$ and monthly and annual total rainfall (mm) experienced at the two trial sites during 2010 are shown in Figure 1. Annual rainfall was $671 \mathrm{~mm}$ in the interior dryland (Experiment I) and $902 \mathrm{~mm}$ in the Andean foothills (Experiment II). Around 85\% of total rainfall occurred during the cereal growth season (MayDecember).

\section{Establishment and management of crops}

Legume and oat treatments were established at both sites in 2009, and these were followed by wheat in 2010. The legumes used were field peas (Pisum sativum L. 'Rocket';

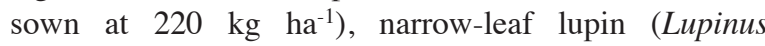
angustifolius L. 'Wonga'; $120 \mathrm{~kg}$ seed $\mathrm{ha}^{-1}$ ) and yellow lupin (Lupinus luteus L. 'Motiv'; $120 \mathrm{~kg} \mathrm{ha}^{-1}$ ) in the interior dryland (Experiment I), and field peas, narrowleaf lupin, and white lupin (Lupinus albus L. 'Rumbo Baer'; $140 \mathrm{~kg} \mathrm{ha}^{-1}$ ) in the Andean foothills (Experiment II). In addition, rotations with green manure consisting of a mixture of vetch (Vicia atropurpurea; unnamed local cultivar; $40 \mathrm{~kg} \mathrm{ha}^{-1}$ ) and oats ('Urano'; $120 \mathrm{~kg} \mathrm{ha}^{-1}$ ) and a cereal rotation (oats-wheat) were used, the latter with $(+\mathrm{N}$ fertilizer) and without (nil $\mathrm{N}$ fertilizer) application of $\mathrm{N}$ fertilizer at both experimental sites.

At the end of the growing season legume residues remaining after grain harvest were chopped and incorporated into the soil 1-mo before seeding the cereal crop. In the case of the vetch + oats green manure treatments, all aboveground material was cut, chopped and then incorporated into the first $20 \mathrm{~cm}$ of soil using disc harrows before grain filling by either species was complete.

The wheat varieties sown at each site were selected on the basis of advice received by wheat breeders and local agronomists about the best performing variety at the two locations. 'Pandora-INIA' (180 kg ha-1, seeding on 25 May 2010) was used for Experiment I and 'Rupanco-INIA' (160 $\mathrm{kg} \mathrm{ha}^{-1}$, seeding 28 May 2010) for Experiment II. Plots

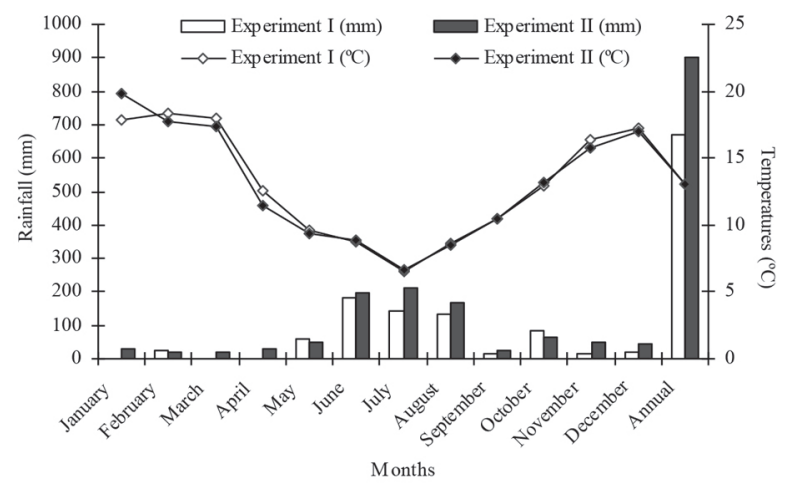

Figure 1. Mean monthly temperatures and monthly and annual total rainfall in Experiment I (Interior dryland) and Experiment II (Andean foothills), in year 2010. 
were sown to a $4 \mathrm{~cm}$ depth at $20 \mathrm{~cm}$ row spacing in $6 \times 3$ $\mathrm{m}$ plots, in a randomized complete block design with four replicates. Applications of $\mathrm{N}$ fertilizer were supplied only to the wheat grown after the $\mathrm{N}$ fertilized oats treatment. Nitrogen as urea was applied at rates of 160 and 207 $\mathrm{kg} \mathrm{N} \mathrm{ha}{ }^{-1}$ in Experiments I and II, respectively (1/3 at sowing, $1 / 3$ at the beginning of tillering, and $1 / 3$ at the end of tillering), as recommended by agricultural advisers and wheat breeders, and as used by many farmers. More details about management and fertilization are provided in Espinoza et al. (2012).

\section{Biomass and yield determination}

Shoot biomass of cereal was sampled for all treatments by harvesting $0.5 \mathrm{~m}$ of a row $\left(0.1 \mathrm{~m}^{2}\right)$. The samples were taken at different growth stages according to the Zadoks scale (as modified by Tottman and Makepeace, 1979): Z24, Z41, Z59, Z75 and Z91, that is, at the end of tillering, early-boot stage, end of heading, mid milk development and physiological maturity. Samples were oven-dried with forced air ventilation at $70{ }^{\circ} \mathrm{C}$ until reaching a constant weight for DM determination. Measures of grain yield and vegetative residues (stubble) were obtained by sampling $1 \mathrm{~m}^{2}$ from each treatment plot at wheat maturity on 9 December 2010 in Experiment I and on 17 January 2011 in Experiment II.

\section{Determination of soil $\mathbf{N}$ mineralization and $\operatorname{shoot} \mathbf{N}$}

A modified version of the in situ soil incubation method, proposed by Raison et al. (1987), was used to determine soil $\mathrm{N}$ mineralization. At the beginning of the experiment after sowing the crop, five PVC tubes $(25 \mathrm{~cm}$ long $10 \mathrm{~cm}$ in diameter), one for each sampling stage, were installed between wheat rows in each experimental unit without disturbing the soil. Periodically, a tube was collected from each experimental unit according to the wheat phenological stages Z24, Z41, Z59, Z75 and Z91. Each sample was subjected to mineral $\mathrm{N}$ analysis by $2 \mathrm{~N} \mathrm{KCl}$ 1:10 extraction and colorimetric determination with a flow segmented injection autoanalyzer (SKALAR, SA 4000, Breda, The Netherlands). N mineralized $\left(\mathrm{kg} \mathrm{ha}^{-1}\right)$ in the first $20 \mathrm{~cm}$ was calculated using the apparent density of the soil: 1.84 and $0.86 \mathrm{~g} \mathrm{~cm}^{-3}$ for the interior dryland and Andes foothill, respectively.

Shoot $\mathrm{N}$ concentration was evaluated by the Kjeldahl digestion method and the shoot $\mathrm{N}$ content $\left(\mathrm{kg} \mathrm{N} \mathrm{Na}^{-1}\right)$ determined as:

$$
\text { Shoot } N=[\text { shootDM } \cdot N \text { concentration }(\%)] / 100
$$

\section{Nitrogen use efficiencies}

Nitrogen efficiencies were calculated according LópezBellido and López-Bellido (2001); N use efficiency (NUE) was calculated as the ratio of grain yield to $\mathrm{N}$ supply, where $\mathrm{N}$ supply is the sum of soil $\mathrm{NO}_{3}{ }^{-} \mathrm{N}$ at sowing, mineralized $\mathrm{N}$, and $\mathrm{N}$ fertilizer:

$$
N U E=[G Y /(B+C)]
$$

where $G Y$ is wheat grain yield $\left(\mathrm{kg} \mathrm{ha}^{-1}\right), B$ is soil $\mathrm{NO}_{3}^{-}-\mathrm{N}$ at sowing $\left(\mathrm{kg} \mathrm{ha}^{-1}\right)$, and $C$ is the mineralized $\mathrm{N}\left(\mathrm{kg} \mathrm{ha}^{-1}\right)$. Nitrogen uptake efficiency $\left(\mathrm{NU}_{\mathrm{p}} \mathrm{E}\right)$ was calculated as the ratio of total shoot $\mathrm{N}$ ( $\mathrm{N}$ uptake; $\mathrm{kg} \mathrm{N} \mathrm{ha}^{-1}$ ) to $\mathrm{N}$ supply, where $\mathrm{N}$ supply is the sum of soil $\mathrm{NO}_{3}{ }^{-}-\mathrm{N}$ at sowing, mineralized $\mathrm{N}$ and $\mathrm{N}$ fertilizer:

$$
N U_{p} E=[\operatorname{Shoot} N /(B+C)]
$$

Finally, the $\mathrm{N}$ utilization efficiency $\left(\mathrm{NU}_{\mathrm{t}} \mathrm{E}\right)$ was calculated as the ratio of grain yield to total plant $\mathrm{N}$ uptake:

$$
N U_{t} E=(G Y / \operatorname{Shoot} N)
$$

\section{Statistical analyses}

All data were subjected to an ANOVA $(\mathrm{P} \leq 0.05)$ after a normality test. Mean separation was done by Duncan's multiple range test. All statistical analyses were carried out with the SAS program (SAS Institute, Cary, North Carolina, USA) for Windows V8.

\section{RESULTS}

\section{Dry matter production and shoot $\mathrm{N}$ accumulated by legumes}

Biomass production, grain yields, and $\mathrm{N}$ contribution of the different grain legumes in the rotation were reported previously in Espinoza et al. (2012). Nevertheless, to provide an overview of the effect of crop rotations, the main results are summarized in this article. In the interior dryland (Experiment I), the highest level of DM production was obtained with field peas $\left(10.9 \mathrm{Mg} \mathrm{ha}^{-1}\right)$, followed by narrow-leaf lupin $\left(6.54 \mathrm{Mg} \mathrm{ha}^{-1}\right)$, yellow lupin (5.5 $\left.\mathrm{Mg} \mathrm{ha}^{-1}\right)$, and green manure (vetch + oats, 1.7 $\left.\mathrm{Mg} \mathrm{ha}^{-1}\right)$. The highest aboveground biomass production in the Andean foothills (Experiment II) was obtained with white lupin $\left(12 \mathrm{Mg} \mathrm{ha}^{-1}\right)$, followed by narrow-leaf lupin $\left(10.9 \mathrm{Mg} \mathrm{ha}^{-1}\right)$, field peas $\left(8.6 \mathrm{Mg} \mathrm{ha}^{-1}\right)$, and green manure (vetch + oats, $3.3 \mathrm{Mg} \mathrm{ha}^{-1}$ ). The amount of shoot $\mathrm{N}$ in grain legumes in 2009 ranged between 138 and 208 in the interior dryland, and 210-349 $\mathrm{kg} \mathrm{N} \mathrm{ha}^{-1}$ (average $2 \mathrm{yr}$ ) in the Andean foothills; lower amounts of shoot $\mathrm{N}$ were attained in vetch. The net inputs of fixed $\mathrm{N}$ returned to the soil ranged between 36 and $176 \mathrm{~kg} \mathrm{~N} \mathrm{ha}^{-1}$ in the interior dryland, and 0-227 $\mathrm{kg} \mathrm{N} \mathrm{ha}^{-1}$ in the Andean foothills; the highest values were obtained with field peas in the interior dryland, and with white lupin and field peas in the Andean foothills (Espinoza et al., 2012).

\section{Available soil N prior to sowing wheat}

Nitrate concentration in the top $20 \mathrm{~cm}$ of soil in the interior dryland (Experiment I) prior to sowing the subsequent wheat crop was higher after field peas $(61 \mathrm{~kg}$ $\left.\mathrm{N} \mathrm{ha}^{-1}\right)$, white lupin or narrow-leaf lupin $\left(60 \mathrm{~kg} \mathrm{~N} \mathrm{ha}^{-1}\right)$, with no significant differences $(\mathrm{P} \leq 0.05)$ between them. After green manure (vetch + oats) and oats without $\mathrm{N}$ fertilizer soil nitrate was $50 \%$ lower, and after oats with $\mathrm{N}$ fertilizer the value was even lower (Figure 2). Soil nitrate 


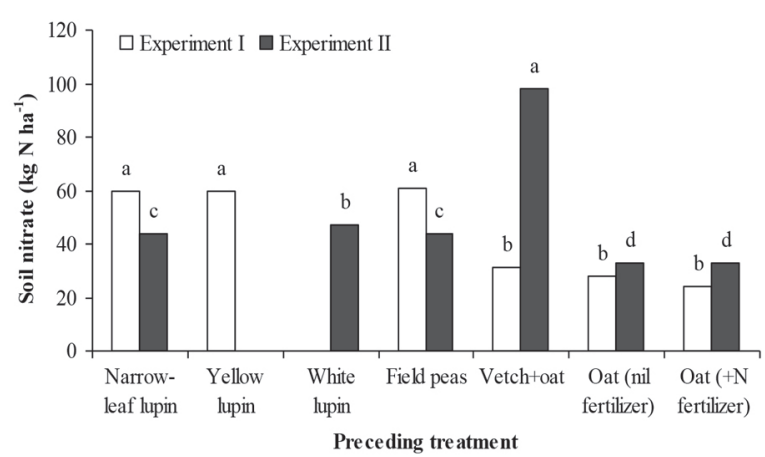

Means with different letters within the experiment differ according to Duncan's multiple test $(\mathrm{P} \leq 0.05)$.

Figure 2. Treatment effects on concentrations of soil nitrate (0-20 cm) measured in autumn 2010 prior to sowing wheat Experiment I (Interior dryland) and Experiment II (Andean foothills).

content was higher in the Andean foothills (Experiment II) compared with the interior dryland (Figure 2). The highest values were observed after green manure (vetch + oats) (98 $\mathrm{kg} \mathrm{N} \mathrm{ha}^{-1}$ ) and the lowest were detected after oats, with and without $\mathrm{N}$ fertilizer $\left(33 \mathrm{~kg} \mathrm{~N} \mathrm{ha}^{-1}\right)$. Narrowleaf lupin and field peas showed intermediate values of soil nitrate content (Figure 2).

\section{Mineral $\mathbf{N}$ in growing season and calculation $\mathbf{N}$ available for plant growth}

The concentration of soil mineral $\mathrm{N}$ measured within the in situ incubation tubes at wheat tillering was in general lower than originally measured in the top $20 \mathrm{~cm}$ of soil prior to sowing (Figure 3). In the interior dryland (Experiment I) the available soil $\mathrm{N}$ at tillering (Z24) ranged between $16-18 \mathrm{~kg} \mathrm{~N} \mathrm{ha}^{-1}$ in rotations with field peas, green manure (vetch + oats) and cereal monoculture with N (Figures 3c, $3 \mathrm{~d}$, and $3 \mathrm{f}$ ). Lower values were observed in the rotations with two lupin species, ranging between 11 and $13 \mathrm{~kg} \mathrm{~N}$ $\mathrm{ha}^{-1}$ (Figures 3a and 3b). The lowest value was with the cereal monoculture without $\mathrm{N}$ fertilizers, which had 8 $\mathrm{kg} \mathrm{N}^{-1}$ (Figure 3e). After tillering there was a strong increase in soil $\mathrm{N}$ over time, reaching values of $100 \mathrm{~kg} \mathrm{~N}$ $\mathrm{ha}^{-1}$ at physiological maturity (Z91) in the rotations with lupins, field pea, and cereal monoculture with $\mathrm{N}$ (Figures $3 \mathrm{a}, 3 \mathrm{~b}, 3 \mathrm{c}$, and $3 \mathrm{f})$. In the rotations with green manure (vetch + oats) or nil $\mathrm{N}$, cereal monoculture had the lowest values between 78 and $58 \mathrm{~kg} \mathrm{~N} \mathrm{ha}^{-1}$, respectively (Figures $3 \mathrm{~d}$ and $3 \mathrm{e}$ ). In the Andean foothills (Experiment II) the initial available soil $\mathrm{N}$ content at tillering ranged between $18-19 \mathrm{~kg} \mathrm{ha}^{-1}$ in the rotations with green manure (vetch + oats) and the cereal monoculture with $\mathrm{N}$ (Figures $4 \mathrm{~d}$ and $4 \mathrm{f}$ ). Lower values were observed in the rotations with field pea and white lupin (10 and $13 \mathrm{~kg} \mathrm{~N} \mathrm{ha}^{-1}$ ) (Figures $4 \mathrm{~b}$ and $4 \mathrm{c}$ ). The lowest values were observed in the narrowleaf lupin and cereal monoculture without $\mathrm{N}$ fertilizers, which on average were $10 \mathrm{~kg} \mathrm{~N}^{-1}$ (Figures $4 \mathrm{a}$ and $4 \mathrm{e}$ ). At maturity, the highest soil $\mathrm{N}$ content was $94 \mathrm{~kg} \mathrm{~N}^{-1}$ with green manure (vetch + oats), followed by cereal monoculture with $\mathrm{N}$ fertilizers (86 $\mathrm{kg} \mathrm{N} \mathrm{ha}^{-1}$ ) (Figures $4 \mathrm{~d}$ and $4 \mathrm{f}$ ). Lupins and field pea presented intermediate soil available $\mathrm{N}$ values (average $67 \mathrm{~kg} \mathrm{ha}^{-1}$ ) (Figures $4 \mathrm{a}, 4 \mathrm{~b}$, and $4 \mathrm{c}$ ). The lowest value was $56 \mathrm{~kg} \mathrm{~N}^{-1}$ in the nil $\mathrm{N}$ cereal monoculture (Figure 4e).

Assuming that no wheat roots were present in any of the in situ incubation tubes, and assuming that soil $\mathrm{N}$ dynamics occurring within tubes mimicked what occurred in the bulk soil, changes in soil available $\mathrm{N}$ derived from Figure 3 suggested that level of net mineralization at tillering and physiological maturity in the interior dryland ranged $84-87 \mathrm{~kg} \mathrm{~N}^{\mathrm{N}} \mathrm{ha}^{-1}$ following grain legumes, $60 \mathrm{~kg} \mathrm{~N}^{-1}$ following green manure, and 83 and $50 \mathrm{~kg} \mathrm{~N} \mathrm{ha}^{-1}$ following oats with and without $\mathrm{N}$ fertilizers, respectively. In the Andean foothills, net mineralization level ranged 53-60 $\mathrm{kg} \mathrm{N}^{-1}$ following grain legumes, $76 \mathrm{~kg} \mathrm{~N} \mathrm{ha}^{-1}$ following green manure, and 67 and $47 \mathrm{~kg} \mathrm{~N}^{-1}$ following oats with and without $\mathrm{N}$ fertilizers, respectively (Figure 4).

On the basis of the soil mineral $\mathrm{N}$ present prior to sowing (Figure 2) and the estimates of net mineralization from tillering to physiological maturity, it was calculated that total amounts of soil mineral $\mathrm{N}$ available for uptake by wheat during the entire growing season ranged 78-150 and $80-174 \mathrm{~kg} \mathrm{~N} \mathrm{ha}^{-1}$ in the interior dryland and Andean foothills, respectively. The lowest values were following oats without $\mathrm{N}$ fertilizers in both environments, and the highest ones were following grain legumes in the interior dryland, and following green manure in the Andean foothills.

\section{Wheat shoot dry matter, grain yield, and $\mathrm{N}$ content}

Wheat shoot DM increased exponentially in all the rotations in the interior dryland (Experiment I) beginning at tillering (day 93, Z24). At maturity, significant differences $(\mathrm{P} \leq 0.05)$ were observed in shoot $\mathrm{DM}$ according to the preceding crop in the rotation: a) field peas and oats $(+\mathrm{N})$; b) narrow-leaf and yellow lupin; and c) green manure (vetch + oats) and nil $\mathrm{N}$ oats (Table 1$)$. Similar results were observed for grain yield except that no significant differences were detected following narrow-leaf lupin and field peas (Table 1). Shoot $\mathrm{N}$ content of wheat also showed an exponential increase from tillering until maturity in all the rotations (Figure 3 ). At heading, shoot $\mathrm{N}$ represented $31-52 \%$ of total $\mathrm{N}$ at maturity in the different rotations (Table 1). The maximum values at physiological maturity differed significantly $(\mathrm{P} \leq 0.05)$ among treatments; shoot $\mathrm{N}$ was higher in the monoculture rotation with $\mathrm{N}$ fertilizers, followed by field peas and lupins (Table 1). The lowest $\mathrm{N}$ values in aboveground cereal biomass were observed with green manure (vetch + oats) and nil $\mathrm{N}$ cereal monoculture (Table 1). The shoot $\mathrm{N}$ concentration was similar in the different rotations except for the monoculture rotation with $\mathrm{N}$ fertilizer (Table 1).

Similar increase in soil availability and shoot $\mathrm{N}$ content over time was observed in the Andean foothill 

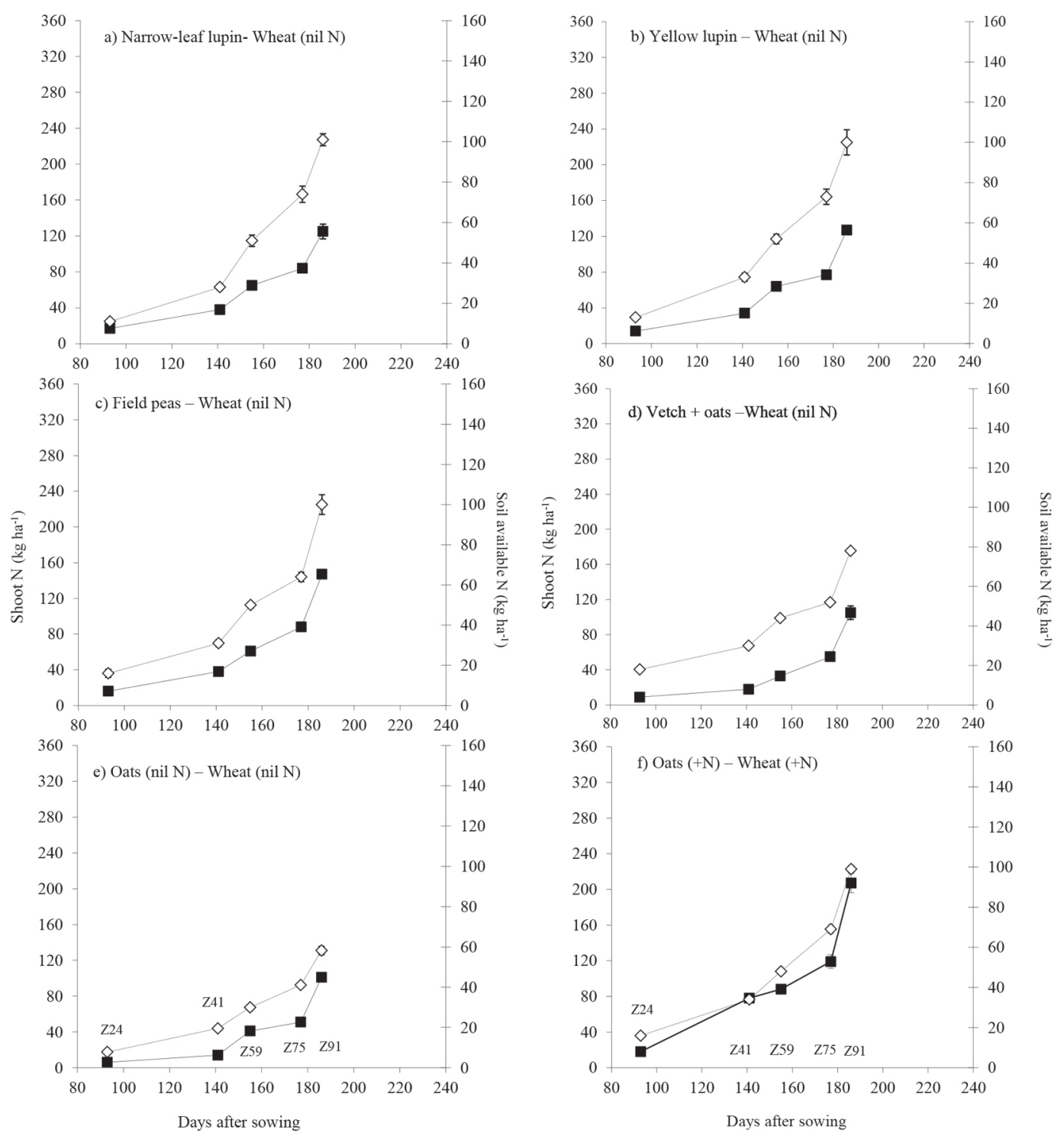

Zadoks scale Z24, Z41, Z59, Z75 and Z91 correspond to end of tillering, early-boot stage, heading, mid milk development and physiological maturity, respectively.

Figure 3. Time variation of soil available $\mathbf{N}(\diamond)$ and shoot $\mathbf{N}$ content $(-\varpi)$ of wheat preceded by a rotation with three grain legumes $(a, b, c)$, green manure (vetch+oats; d), and oats with and without $\mathrm{N}$ fertilizer (e, f) growing in Experiment I (Interior dryland).

site (Experiment II) (Figure 4). Shoot DM of wheat was significantly $(\mathrm{P}<0.05)$ different among rotations; the highest values were observed following green manure (vetch + oats), field peas or oats $(+\mathrm{N})$, then following narrow-leaf lupin or white lupin, and the lowest following nil $\mathrm{N}$ oats (Table 1). Grain yield was higher in the Andes foothills (average $5.9 \mathrm{t} \mathrm{ha}^{-1}$ ) than in the interior dryland site (average $\left.2.3 \mathrm{t} \mathrm{ha}^{-1}\right)$. The highest wheat yield was observed following green manure or oats $(+\mathrm{N})$, then when following field peas (Table 1). Shoot $\mathrm{N}$ content over time showed an exponential tendency in all the rotations (Figure 4), where $42-59 \%$ of the total $\mathrm{N}$ was absorbed at heading (Table 1). The highest shoot $\mathrm{N}$ content at tillering occurred in the cereal monoculture with $\mathrm{N}$ fertilizer $\left(131 \mathrm{~kg} \mathrm{~N} \mathrm{ha}^{-1}\right)$. The other crop rotations did not present significant differences $(\mathrm{P} \leq 0.05)$ in shoot $\mathrm{N}$ (average $59 \mathrm{~kg} \mathrm{ha}^{-1}$ ) at this crop development stage. However, at maturity differences among the rotations were more evident, with the cereal monoculture with $\mathrm{N}$ and green manure (vetch + oats) obtaining the highest values of $\mathrm{N}$ concentration and shoot $\mathrm{N}$ content, followed by lupins and field peas (Table 1). In the cereal monoculture rotation without $\mathrm{N}$ fertilizer, shoot $\mathrm{N}$ reached $41 \%$ of rotation with green manure (Table 1).

Using the data for all rotations except for cereal monoculture with $\mathrm{N}$ fertilizer, positive linear relationships were observed between available soil $\mathrm{N}$ measured in incubation tubes as a surrogate for $\mathrm{N}$ mineralization and shoot $\mathrm{N}$ accumulation in both environments $\left(\mathrm{R}^{2}=0.45\right.$; 

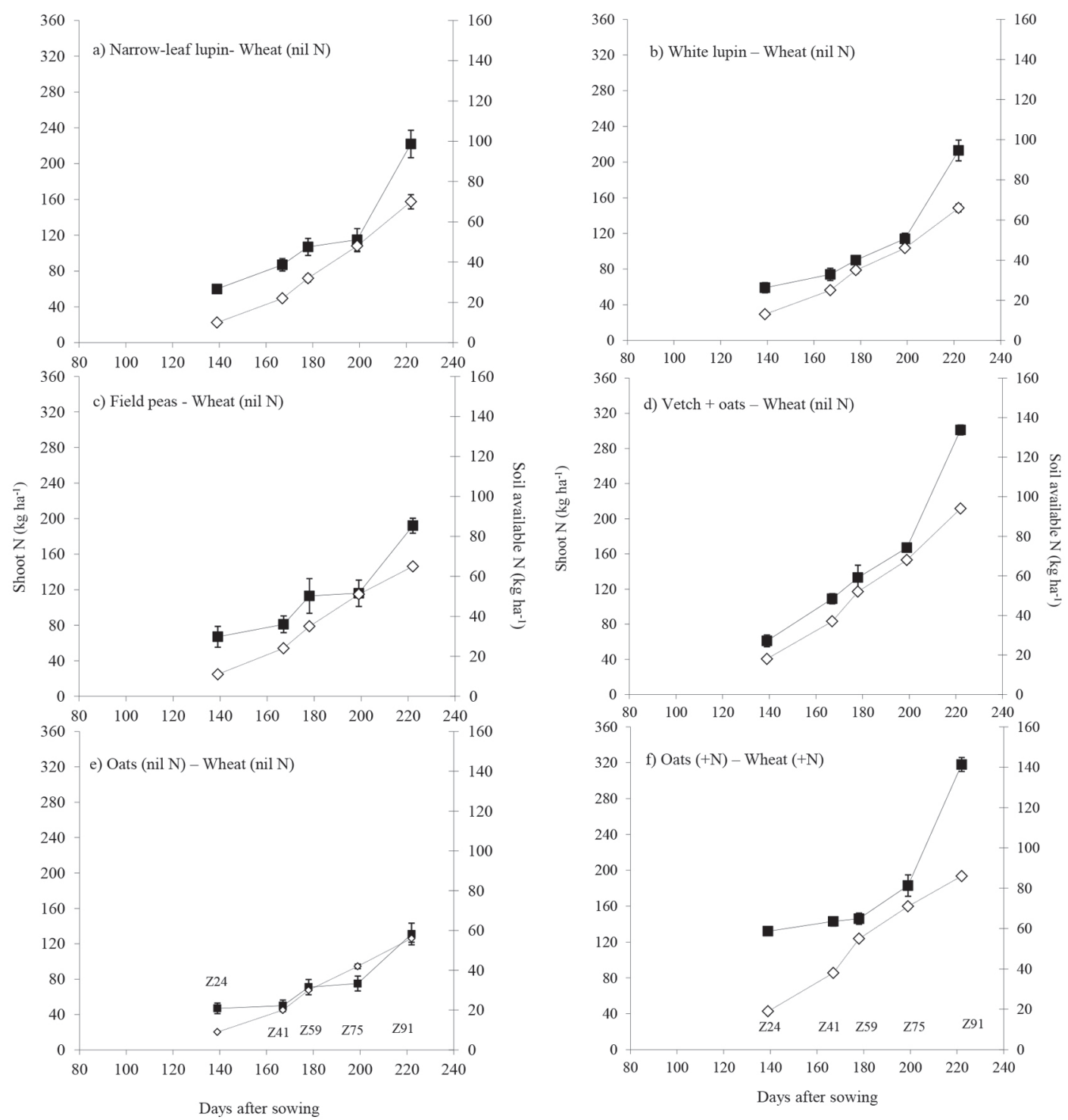

Zadoks scale Z24, Z41, Z59, Z75 and Z91 correspond to end of tillering, early-boot stage, heading, mid milk development and physiological maturity, respectively.

Figure 4. Time variation of soil available $N(\diamond)$ and shoot $N$ content $(\square)$ of wheat preceded by a rotation with three grain legumes (a, b, c), green manure (vetch+oats; d), and oats with and without $\mathrm{N}$ fertilizer (e, f) growing in Experiment II (Andean foothills).

$\mathrm{P} \leq 0.05$ in the interior dryland and $0.84, \mathrm{P} \leq 0.001$ in the Andean foothills). However, shoot $\mathrm{N}$ in the Andean foothills was much higher at any level of measured soil mineral N, compared to the interior dryland (Figure 5).

\section{Nitrogen use efficiencies}

The relationship between grain yield and estimates of the amounts of soil mineral $\mathrm{N}$ available for crop uptake $\mathrm{N}$ mineralization, considering all the rotations except the cereal monoculture with $\mathrm{N}$ fertilizer, was linear but clearly different in the two environments (Figure 6); the slope of the regression was more than double in the Andes foothills and also grain yield was higher at any value of soil $\mathrm{N}$, compared to the interior dryland. The relationship between wheat yield and shoot $\mathrm{N}$ content in all the rotations, except the cereal monoculture with $\mathrm{N}$ fertilizer, was also different between environments (Figure 7); a much wider range of shoot $\mathrm{N}$ values was observed in the Andes foothills, but the slope of the regression was higher in the interior dryland.

NUE was on average 15 and $42 \mathrm{~kg}_{\text {grain }} \mathrm{kg}^{-1} \mathrm{~N}$ supply in the interior dryland and the Andes foothills, respectively (Table 2). Significant differences were found among rotations in both environments; in the interior dryland the highest NUE values were recorded following narrow-leaf lupin, field peas, or yellow lupin, while the lowest were observed following oats with $\mathrm{N}$ fertilizer. In the Andes foothills, the highest NUE was 
Table 1. Shoot dry matter, grain yield, $\mathbf{N}$ concentration in the biomass and shoot $\mathrm{N}$ content of wheat at maturity in crop sequences with legumes in Experiments I and II in 2010.

\begin{tabular}{|c|c|c|c|c|}
\hline $\begin{array}{l}\text { Experiment and } \\
\text { crop sequence }\end{array}$ & $\begin{array}{c}\text { Shoot } \\
\text { dry } \\
\text { matter }\end{array}$ & $\begin{array}{l}\text { Grain } \\
\text { yield } \mathrm{c}\end{array}$ & $\begin{array}{c}\mathrm{N} \\
\text { concentration }\end{array}$ & $\mathrm{n} \begin{array}{c}\text { Shoot } \\
\mathrm{N} \\
\text { content }\end{array}$ \\
\hline & kg DM ha-1 & $\mathrm{Mg} \mathrm{ha}^{-1}$ & $\%$ & $\mathrm{~kg} \mathrm{~N} \mathrm{ha}^{-1}$ \\
\hline & \multicolumn{4}{|c|}{ Experiment I. Interior dryland } \\
\hline Narrow-leaf lupin-wheat (nil N) & $10080 b$ & $3.00 \mathrm{ab}$ & $1.24 \mathrm{~b}$ & $125 \mathrm{c}$ \\
\hline Yellow lupin- wheat (nil N) & $9879 b$ & $2.66 \mathrm{~b}$ & $1.25 \mathrm{~b}$ & $123 \mathrm{c}$ \\
\hline Field peas-wheat (nil N) & $11927 \mathrm{a}$ & $2.89 \mathrm{ab}$ & $1.23 \mathrm{~b}$ & $147 b$ \\
\hline Vetch + oats-wheat (nil N) & $8812 \mathrm{c}$ & $1.66 \mathrm{~d}$ & $1.19 \mathrm{~b}$ & 105de \\
\hline Oats (nil N)-wheat (nil N) & $8785 \mathrm{c}$ & $1.12 \mathrm{~d}$ & $1.15 b$ & $101 d$ \\
\hline \multirow[t]{2}{*}{ Oats $(+\mathrm{N})$-wheat $(+\mathrm{N})$} & $11928 \mathrm{a}$ & $2.73 \mathrm{ab}$ & $1.74 \mathrm{a}$ & $208 \mathrm{a}$ \\
\hline & \multicolumn{4}{|c|}{ Experiment II. Andean foothills } \\
\hline Narrow-leaf lupin-wheat (nil N) & $15246 b$ & $5.44 \mathrm{c}$ & $1.45 \mathrm{~b}$ & $222 b(48.2)$ \\
\hline White lupin-wheat (nil N) & $14514 b$ & $5.35 \mathrm{c}$ & $1.47 \mathrm{~b}$ & $213 b(42.3)$ \\
\hline Field peas-wheat (nil N) & $16766 \mathrm{a}$ & $6.21 b$ & $1.14 \mathrm{c}$ & $192 b(58.9)$ \\
\hline Vetch + oats-wheat (nil N) & $17654 a$ & $7.67 \mathrm{a}$ & $1.71 \mathrm{a}$ & $302 \mathrm{a}(58.9)$ \\
\hline Oats (nil N)-wheat (nil N) & $11012 \mathrm{c}$ & $3.46 \mathrm{~d}$ & $1.19 \mathrm{c}$ & $131 \mathrm{c}(54.2)$ \\
\hline Oats $(+\mathrm{N})$-wheat $(+\mathrm{N})$ & $17409 a$ & $7.50 \mathrm{a}$ & $1.83 \mathrm{a}$ & $319 \mathrm{a}(45.9)$ \\
\hline
\end{tabular}

Means followed by different letters in the same column differ according to Duncan's multiple test $(\mathrm{P} \leq 0.05)$ for Experiment.

Values in brackets represent the percentage of shoot $\mathrm{N}$ content at heading.

obtained after field peas and the lowest after oats with $\mathrm{N}$ fertilizers (Table 2). On average $\mathrm{NU}_{\mathrm{p}} \mathrm{E}$ was 0.88 and 1.61 $\mathrm{kg} \mathrm{N}$ shoot per kilogram soil $\mathrm{N}$ supplied in the interior dryland and the Andes foothills, respectively (Table 2). This efficiency was similar following the different legume crops in the interior dryland, but higher following oats without $\mathrm{N}$ fertilizer. In the Andean foothills the highest $\mathrm{NU}_{\mathrm{p}} \mathrm{E}$ was recorded following lupins and significantly different $(\mathrm{P} \leq 0.05)$ from the cereal monoculture with $\mathrm{N}$ fertilizers (Table 2). The $\mathrm{N}$ utilization efficiency $\left(\mathrm{NU}_{\mathrm{t}} \mathrm{E}\right)$ was on average similar in both environments (Table 2). In the interior dryland, $\mathrm{NU}_{\mathrm{t}} \mathrm{E}$ was greater following legumes compared to cereal rotations, but this was not the case in the Andean foothills where the values were more similar among the different rotations (Table 2).

Table 2. Nitrogen use efficiency (NUE), $\mathbf{N}$ uptake efficiency $\left(\mathrm{NU}_{\mathrm{p}} \mathrm{E}\right)$, and $\mathbf{N}$ utilization efficiency $\left(\mathrm{NU}_{\mathrm{t}} \mathrm{E}\right)$ in rotations with grain legumes, green manure and cereal with and without $N$, in Experiment $I$ and Experiment II.

\begin{tabular}{|c|c|c|c|}
\hline Experiment and crop sequence & NUE & $\mathrm{NU}_{\mathrm{p}} \mathrm{E}$ & $\mathrm{NU}_{\mathrm{t}} \mathrm{E}$ \\
\hline & $\mathrm{kg}$ grain $\mathrm{kg}^{-1}$ & kg uptake $\mathrm{kg}^{-1}$ & $\mathrm{~kg}$ grain $\mathrm{kg}^{-1}$ \\
\hline & N supply & N supply & N uptake \\
\hline & \multicolumn{3}{|c|}{ Experiment I. Interior dryland } \\
\hline Narrow-leaf lupin-wheat (nil N) & $19 \mathrm{a}$ & $0.78 \mathrm{de}$ & $24 a$ \\
\hline Yellow lupin-wheat (nil N) & $17 \mathrm{ab}$ & $0.80 \mathrm{dc}$ & $21 b$ \\
\hline Field peas-wheat (nil N) & $18 \mathrm{a}$ & $0.91 \mathrm{bc}$ & $20 \mathrm{~b}$ \\
\hline Vetch + oats-wheat (nil N) & $15 \mathrm{bc}$ & $0.97 b$ & $16 \mathrm{c}$ \\
\hline Oats (nil N)-wheat (nil N) & $13 \mathrm{c}$ & $1.16 \mathrm{a}$ & $11 d$ \\
\hline \multirow[t]{2}{*}{ Oats $(+\mathrm{N})$-wheat $(+\mathrm{N})$} & $10 \mathrm{~d}$ & $0.67 \mathrm{e}$ & $15 \mathrm{~cd}$ \\
\hline & \multicolumn{3}{|c|}{ Experiment II. Andean foothills } \\
\hline Narrow-leaf lupin-wheat (nil N) & $48 b$ & $1.94 \mathrm{a}$ & $25 b$ \\
\hline White lupin-wheat (nil N) & $47 \mathrm{~b}$ & $1.88 \mathrm{a}$ & $26 a b$ \\
\hline Field peas-wheat (nil N) & $57 \mathrm{a}$ & $1.77 \mathrm{ab}$ & $33 \mathrm{a}$ \\
\hline Vetch + oats-wheat (nil N) & $40 \mathrm{c}$ & $1.58 \mathrm{bc}$ & $25 \mathrm{ab}$ \\
\hline Oats (nil N)-wheat (nil N) & $39 \mathrm{c}$ & $1.49 \mathrm{c}$ & $27 \mathrm{ab}$ \\
\hline Oats $(+\mathrm{N})$-wheat $(+\mathrm{N})$ & $23 \mathrm{~d}$ & $0.98 \mathrm{~d}$ & $24 b$ \\
\hline
\end{tabular}

Means followed by different letters in the same column differ according to Duncan's multiple test $(\mathrm{P} \leq 0.05)$ for experiment.

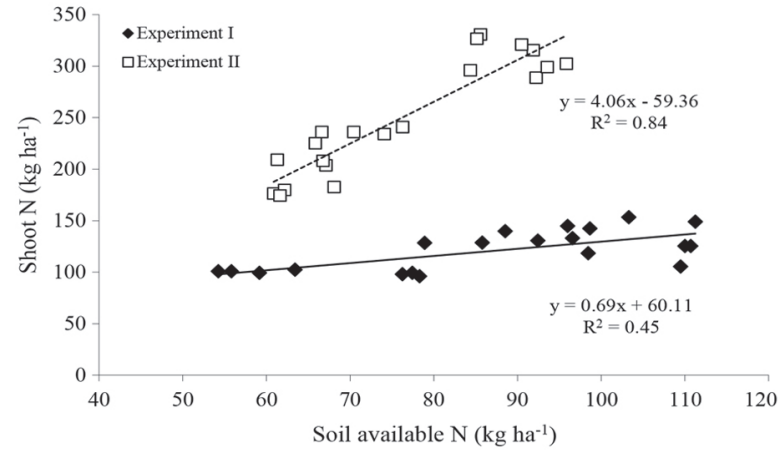

Figure 5. Relationship between soil available $\mathbf{N}$ and shoot $\mathbf{N}$ content for Experiment I (Interior dryland) and Experiment II (Andean foothills). Data from cereal monoculture with $\mathrm{N}$ fertilizer were not included.

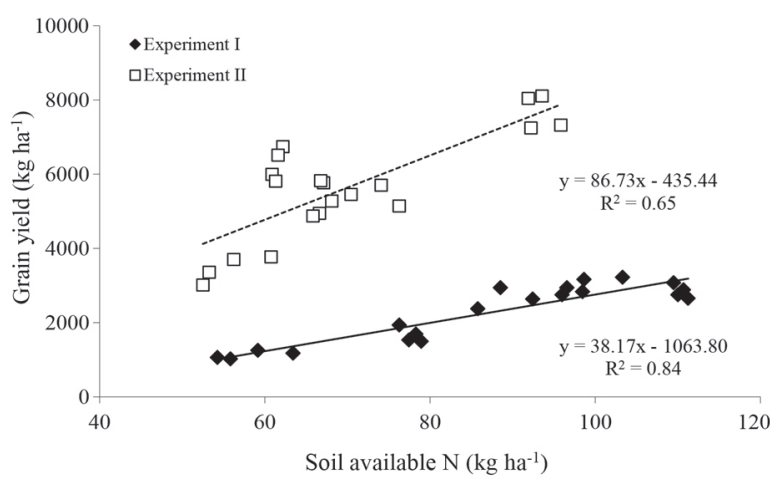

Figure 6. Relationship between soil available $\mathbf{N}$ and grain yield for Experiment I (Interior dryland) and Experiment II (Andean foothills). Data from cereal monoculture with $\mathrm{N}$ fertilizer were not included.

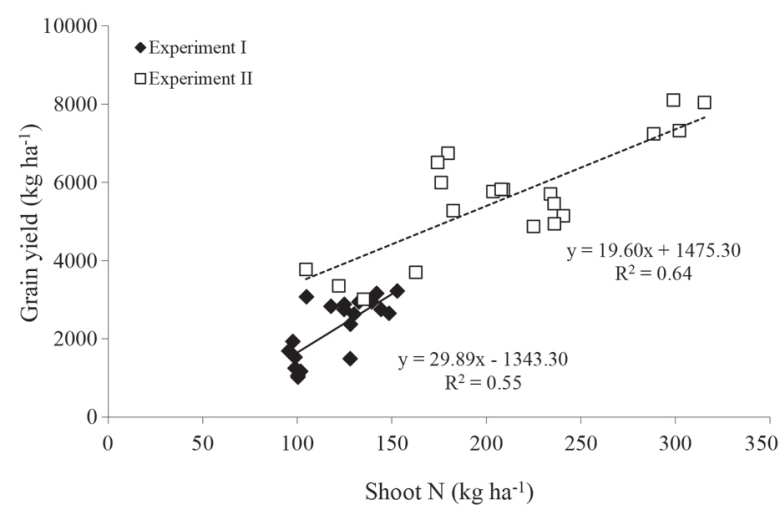

Figure 7. Relationship between grain yield and shoot $\mathrm{N}$ content for Experiment I (Interior dryland) and Experiment II (Andean foothills). Data from cereal monoculture with $\mathrm{N}$ fertilizer were not included.

\section{DISCUSSION}

The soil available $\mathrm{N}$ in the top $20 \mathrm{~cm}$ prior to sowing wheat do not corresponds to the net inputs of fixed $\mathrm{N}$ or the amount of residual $\mathrm{N}$ from legume crops or green manure remaining at the end of the growing season (Espinoza et al., 2012). 
Part of the available soil N could have leached below $20 \mathrm{~cm}$ before tillering where more than $400 \mathrm{~mm}$ rainfall occurred at both experimental sites between the initial pre-sowing soil sampling and collection of the first soil samples from the incubation tubes at tillering (Figure 1). This assumption was confirmed by the lysimeter data collected from the Andean foothills, which suggested that about $30 \mathrm{~kg} \mathrm{~N}$ $\mathrm{ha}^{-1}$ were leached below $60 \mathrm{~cm}$ during this portion of the growing season (data not shown).

Rainfall following tillering was relatively low (100 and $75 \mathrm{~mm}$ for Experiments I and II, respectively), and the lysimeter data suggest little deep leaching of mineral $\mathrm{N}$. Consequently, the subsequent accumulation of soil mineral $\mathrm{N}$ that was observed between tillering and maturity was assumed to provide a reasonable estimate of soil $\mathrm{N}$ mineralization occurring during this important period of crop development (Figure 3).

The wheat shoot $\mathrm{N}$ content exhibited a close relationship to soil $\mathrm{N}$ availability in both environments. The differences between the two sites in shoot $\mathrm{N}$ content can be attributed to genetic differences of cultivars (Le Gouis et al., 2000) and environmental factors like temperature, humidity, water availability, and soil $\mathrm{N}$ content (Papakosta and Gagianas, 1991). The total N content in wheat at heading in the different rotations and environments was lower than previously reported by other authors (Sun et al., 2012). This can be explain by the increase in $\mathrm{N}$ mineralization rate late in the spring in these dryland environments, leading to higher availability of soil $\mathrm{N}$ after heading (Figures 3 and 4).

At the end of the growing season for a legume crop, the aboveground residues and the organic matter below the surface (roots and nodules) are the reservoirs for mineralization. Several studies report that $\mathrm{N}$ associated with nodules and roots can represent between $30 \%$ and $60 \%$ of total $\mathrm{N}$ accumulated by legumes (Khan et al., 2003; McNeill and Fillery, 2008). In a study of a legumecereal sequence in a Mediterranean climate in Australia, wheat used between $3-10 \%$ of belowground lupin $\mathrm{N}$ after being labeled with ${ }^{15} \mathrm{~N}$ (McNeill and Fillery, 2008). A similar investigation undertaken elsewhere examining a faba bean (Vicia faba L.) - wheat sequence suggested that wheat may recover more than twice the amount of $\mathrm{N}$ from residual $\mathrm{N}$ associated with faba bean nodulated roots than from shoot residues (Jensen et al.2010). Such studies clearly demonstrate that legume roots and nodules can be an important source of $\mathrm{N}$ for following crops.

Estimates of soil $\mathrm{N}$ mineralization obtained with incubation tubes in Experiment I (interior dryland) were higher than measures of crop $\mathrm{N}$ uptake, probably because $\mathrm{N}$ assimilation was limited by low water availability (Figure 3). Experiment I was established on a degraded Alfisol with a high level of clay and low organic matter in the soil profile, which has low water infiltration characteristics that increase runoff and reduce water holding capacity compared to the Andisol of the Andean foothills (Alvarez et al., 2012). Many authors have reported that moisture levels have a significant influence on soil $\mathrm{N}$ cycling (mineralization and immobilization) and $\mathrm{N}$ uptake (Khalil et al., 2001). Also, the higher proportion of clay and poor structure of this degraded Alfisol reduced the soil aeration and probably protects the organic matter due to physical and chemical mechanisms, affecting $\mathrm{N}$ mineralization (Robertson and Groffman, 2007).

More $\mathrm{N}$ was accumulated in plants in the Andisol soil of Experiment II (Andean foothills) than was found within the in situ incubation tubes (Figure 4). One possible explanation was that higher $\mathrm{N}$ mineralization rates occurred in the bulk soil than within the incubation tubes. The high organic $\mathrm{N}$ content of these soils $(16 \%$ $\mathrm{OM}$ ) and favorable environmental conditions of aeration, temperature, and humidity are very conducive for $\mathrm{N}$ mineralization (Khalil et al., 2001; Zagal et al., 2003). Presumably, the conditions that prevailed within the incubation tubes did not fully duplicate the conditions experienced in the bulk soil, and/or some nitrate released with the incubation tubes was leached beyond $20 \mathrm{~cm}$.

Another hypothesis to explain the lower predictions of soil $\mathrm{N}$ availability than measured in the crop uptake in the Alfisol could be that roots in the Andisol were likely to have explored a larger soil volume as a consequence of its lighter texture, high water holding capacity and porosity, and good drainage (Shoji et al., 1993). Therefore, roots in the Andisol could have extracted $\mathrm{N}$ from soil regions deeper than the $20 \mathrm{~cm}$ depth limit of the mineralization assessments. Consequently, it would be useful in future experiments to undertake incubations to at least $40 \mathrm{~cm}$ depth in this type of soil. It is also probable that low frequency of samplings in our experiment did not allow for detection of some mineralization peaks produced in sampling time intervals, and therefore mineralization rate could be even higher than the rate detected in this work. Consequently, in future assays the number and frequency of in situ samplings should be increased to capture rapid and momentary mineralization events.

Post-legume cereal yields were between 1.54 and 1.88 $\mathrm{Mg} \mathrm{ha}{ }^{-1}$ higher than yield achieved by the nil $\mathrm{N}$ cereal monoculture sequence (oats-wheat) in the interior dryland site and were between 1.89 and $2.75 \mathrm{Mg} \mathrm{ha}^{-1}$ higher than the cereal system in the Andean foothill site (lupin and field peas), representing an increase in grain yield of between $138 \%$ and $168 \%$ (average 154\%) in the interior dryland and between $55 \%$ and $79 \%$ (average 64\%) in the Andean foothills. Our results are similar to those reported by Rouanet (1989) with Andisols in southern Chile, but higher than yield increases reported by Seymour et al. (2012) in lupin-wheat $\left(0.6 \mathrm{Mg} \mathrm{ha}^{-1}\right)$ and field peas-wheat rotations $\left(0.45 \mathrm{Mg} \mathrm{ha}^{-1}\right)$ in drier environments in Western Australia.

It should be noted that the direct effects of legumes on soil $\mathrm{N}$ fertility are not necessarily the only benefits of rotation for the following crops. Other benefits include 
reduction of diseases in cereals and the consequent reduction in the use of pesticides and fungicides; favoring the establishment of deeper roots, availability of nutrients (e.g. P), soil biology and improved soil structure (Kirkegaard et al., 2008; Peoples et al., 2009). However, in the experiment reported here, cereal yields $(7.67 \mathrm{Mg}$ $\mathrm{ha}^{-1}$ ) with the green manure (vetch + oats)-wheat rotation in the Andean foothill site was similar to those obtained in the cereal rotation fertilized with mineral $\mathrm{N}$, and higher than those obtained with other grain legumes, strongly suggesting that increased soil $\mathrm{N}$ availability was a major factor contributing to the observed improvements in wheat grain yield after legumes (Peoples et al., 2009). The high levels of biomass production from the green manure (8.22 $\mathrm{Mg} \mathrm{ha}^{-1}$ ) incorporated into the soil and the high inputs of fixed $\mathrm{N}$ could explain this result (Espinoza et al., 2012). Other studies about the effects of green manure, such as the narrow-leaf lupin observed by Fowler et al. (2004), indicate that incorporating green manure in a rotation improves yields of subsequent crops. According to Badaruddin and Meyer (1990), the use by wheat of the $\mathrm{N}$ derived from green manure (Medicago sativa L., Melilotus officinalis (L.) Lam., Trifolium pratense L., and Vicia villosa Roth) was better synchronized with the critical phases of $\mathrm{N}$ uptake by the crop. Also, Pierce and Rice (1988) found a high degree of synchronicity between $\mathrm{N}$ uptake by the plant and $\mathrm{N}$ dynamics in a rotation with legumes compared to the contribution of inorganic $\mathrm{N}$ sources. Organic $\mathrm{N}$ tends to be subject to lower losses and was conserved for longer periods of time, contributing to medium and long-term organic $\mathrm{N}$ fertility (Jensen et al., 2010). This is due to replenishment of the pool of potentially mineralizable soil $\mathrm{N}$ and with this the reduction in $\mathrm{N}$ fertilizer requirements. In the interior dryland where soil humidity conditions over the period prior to seeding the wheat crop are unfavorable for biomass degradation once it is incorporated into the soil, the synchrony between $\mathrm{N}$ mineralization and wheat $\mathrm{N}$ uptake appeared to be more restricted.

The $\mathrm{N}$ efficiency indices showed different results depending on the soil type; $\mathrm{N}$ efficiencies were always higher in the Andean foothill site (Table 2). This reflects the chemical, physical and biological characteristics of Andisol soils, leading to higher fertility and water holding capacity, and therefore higher yield potential. According to Urquiaga (2000) and Zagal et al. (2003), the higher NUE in Andisol soils is most likely due to their greater native soil $\mathrm{N}$ availability and the possibility that nutrients are assimilated from considerably deeper than the $20 \mathrm{~cm}$ depth monitored in the current experiment (Stockdale et al. 1997).

In both experimental sites, the $\mathrm{NUE}$ and $\mathrm{NU}_{\mathrm{p}} \mathrm{E}$ after legumes were higher than after oats with $\mathrm{N}$ fertilizers. Similar results have been reported by Badaruddin and Meyer (1994) and López-Bellido and López-Bellido (2001); in this latter study NUE for the cereal monoculture
(13 kg grain $\mathrm{kg}^{-1} \mathrm{~N}$ supply) was lower than for a chickpeabean rotation (16-17 $\mathrm{kg}$ grain $\mathrm{kg}^{-1}$ soil $\mathrm{N}$ supplied), in Typic Haploxererts in a Mediterranean climate in southern Spain. Also, Pierce and Rice (1988) have reported similar NUE values after legumes, although Ma et al. (2003) found lower NUE in a cereal monoculture rotation.

The average $\mathrm{NU}_{\mathrm{p}} \mathrm{E}$ of 0.68 and $1.61 \mathrm{~kg} \mathrm{~N}$ uptake $\mathrm{kg}^{-1}$ $\mathrm{N}$ supply in the interior dryland and Andean foothills, respectively, were higher than the average $0.49 \mathrm{~kg} \mathrm{~N}$ uptake $\mathrm{kg}^{-1} \mathrm{~N}$ supply reported by López-Bellido and López-Bellido (2001). Although both studies were conducted under Mediterranean climate conditions, the differences could be explained by the soils, duration of the experiments, and different legume varieties used. The lower $\mathrm{NU}_{\mathrm{p}} \mathrm{E}$ of the cereal monoculture with $\mathrm{N}$ fertilizers agrees with other reports of lower $\mathrm{NU}_{\mathrm{p}} \mathrm{E}$ as the $\mathrm{N}$ fertilization rate increases (López-Bellido and LópezBellido, 2001; Ma et al., 2003). The higher value of $\mathrm{NU}_{\mathrm{p}} \mathrm{E}$ in the cereal monoculture without fertilization shows the impact of this rotation in depleting soil $\mathrm{N}$.

The average $\mathrm{NU}_{\mathrm{t}} \mathrm{E}$ of 18 and $27 \mathrm{~kg}$ grain $\mathrm{kg}^{-1} \mathrm{~N}$ uptake in the interior dryland and Andean foothills, respectively, were lower than the average $34 \mathrm{~kg}$ grain $\mathrm{kg}^{-1} \mathrm{~N}$ uptake reported by López-Bellido and López-Bellido (2001) in Spain. In the interior dryland the cereal monoculture rotation presented the lowest $\mathrm{NU}_{\mathrm{t}} \mathrm{E}$ of all the rotations (Table 2), thus, increasing fertilization rates led to lower $\mathrm{NU}_{\mathrm{t}} \mathrm{E}$ (Delogu et al., 1998).

\section{CONCLUSIONS}

The use of legume crops (grain or green manure) in the rotation show a clear benefit in terms of soil $\mathrm{N}$ reservoir and its use by the cereal crop in the following season, in the Mediterranean region of central Chile. Wheat yield following legumes crops ranged $60-110 \%$ of the yield observed in fertilized wheat.

There was a close relationship between the soil capacity to mineralize $\mathrm{N}$ and its absorption by cereal crops during the growing season. The highest $\mathrm{N}$ uptake by the cereal crops in the two experimental sites occurred during the end of heading (Z59) and mid milk development (Z75) phenological stages. In the interior dryland, $\mathrm{N}$ uptake was limited by soil water availability and in the Andean foothills it was related to soil $\mathrm{N}$ availability.

The wheat cultivated in both agro-ecological areas after grain legumes or green manure was more efficient in $\mathrm{N}$ uptake and use than the cereal monoculture, especially when the latter was fertilized.

\section{ACKNOWLEDGEMENTS}

This study was whit financial support of Fondo Nacional de Desarrollo Científico and Tecnológico (FONDECYT) Project $N^{\circ} 1080336$. We are grateful to Dr. Mark Peoples 
for his comments and improvements of English in the manuscript, to José Cares for support in statistical analysis, and to Alvaro Arias, research assistant at INIAQuilamapu.

\section{LITERATURE CITED}

Alvarez, J., H.L. Allen, T.J. Albaugh, J.L. Stape, B.P. Bullock, and C. Song. 2012. Factors influencing the growth of radiata pine plantations in Chile. Forestry 0:1-14.

Angus, J.F., T.P. Bolger, J.A. Kirkegaard, and M.B. Peoples. 2006. Nitrogen mineralization in relation to previous crops and pastures. Australian Journal of Soil Research 44:355-365.

Badaruddin, M., and D. Meyer. 1990. Green manure legume effects on soil nitrogen grain yield and nitrogen nutrition of wheat. Crop Science 30:819-825.

Badaruddin, M., and D. Meyer. 1994. Grain legumes effects on soil nitrogen, grain yield, and nitrogen nutrition of wheat. Crop Science 34:1304-1309.

Castillo, D., I. Matus, A. del Pozo, R. Madariaga, and R. Mellado. 2012. Adaptability and genotype $\times$ environment interaction of spring wheat cultivars in Chile using regression analysis, AMMI and SREG. Chilean Journal of Agricultural Research 72:67-174.

Campbell, C.A., and R. De Jong. 2000. Root to straw influence of moisture and rate of $\mathrm{N}$ fertilizer. Canadian Journal of Plant Science 81:39-43.

del Pozo, A., D. Castillo, L. Inostroza, I. Matus, A.M. Méndez, and R. Morcuende. 2012. Improving drought tolerance of barley using Hordeum vulgare subsp. spontaneum as a source of donor alleles in a Hordeum vulgare subsp. vulgare background. Annals of Applied Biology 160:157-167.

Delogu, G., L. Cattivelli, N. Pecchioni, D. De Falcis, T. Maggiore, and A.M. Stanca. 1998. Uptake and agronomic efficiency of nitrogen in winter barley and winter wheat. European Journal of Agronomy 9:11-20.

Espinoza, S., C. Ovalle, E. Zagal, I. Matus, J. Tay, M.B. Peoples, et al. 2012. Contribution of legumes to wheat productivity in Mediterranean environments of central Chile. Field Crop Research 133:150-159.

Fowler, C.J.E., L.M. Condron, and R.D. McLenaghen. 2004. Effects of green manures on nitrogen loss and availability in an organic cropping system. New Zealand Journal of Agricultural Research 47:95-100.

Giacomini, S.J., S. Recous, B. Mary, and C. Aita. 2007. Simulating the effects of $\mathrm{N}$ availability, straw particle size and location in soil on $\mathrm{C}$ and $\mathrm{N}$ mineralization. Plant and Soil 301:289-301.

Guarda, G., S. Padovanand, and G. Delogu. 2004. Grain yield, nitrogen-use efficiency and baking quality of old and modern Italian bread-wheat cultivars grown at different nitrogen levels. European Journal of Agronomy 21:181-192.

Hayat, R., and S. Ali. 2010. Nitrogen fixation of legumes and yield of wheat under legumes-wheat rotation in Pothwar. Pakistan Journal of Botany 42:2317-2326.

Jensen, E.S., M.B. Peoples, and H. Hauggaard-Nielsen. 2010. Faba bean in cropping systems. Field Crops Research 115:203-216

Khan, D.F., M.B. Peoples, G.D. Schwenke, W.L. Felton, D. Chen, and D.F. Herridge. 2003. Effects of below-ground nitrogen on $\mathrm{N}$ balance of field-grown faba bean, chickpea and barley. Australian Journal of Soil Research 54:333-340.

Khalil, M.I., O. Van Cleemput, P. Boeckx, and A.B. Rosenani. 2001. Nitrogen transformations and emission of greenhouse gases from three acid soils of humid tropics amended with $\mathrm{N}$ sources and moisture regime. I. Nitrogen transformations. Soil Science Plant Analysis 32:2893-2907.

Kirkegaard, J., O. Christen, J. Krupinsky, and D. Layzell. 2008. Review: Break crop benefits in temperate wheat production. Field Crops Research 107:185-195.
Le Gouis, J., D. Beghin, E. Heumez, and P. Pluchard. 2000. Genetic differences for nitrogen uptake and nitrogen utilisation efficiencies in winter wheat. European Journal of Agronomy 12:163-173.

López-Bellido, R.J., and L. López-Bellido. 2001. Efficiency of nitrogen in wheat under Mediterranean conditions: effect of tillage, crop rotation and $\mathrm{N}$ fertilization. Field Crop Research 71:31-46.

Ma, B.L., J. Ying, L.M. Dwyer, E.G. Gregorich, and M.J. Morrison. 2003. Crop rotation and soil $\mathrm{N}$ amendment effects on maize production in eastern. Canadian Journal of Soil Science 83:483-495.

McCallum, M.H., J.A. Kirkegaard, T. Green, H.P. Cresswell, S.L. Davies, J.F. Angus, et al. 2004. Improved subsoil macro-porosity following perennial pastures. Australian Journal of Experimental Agriculture 44:299-307.

McNeill, A.M., and I.R.P. Fillery. 2008. Field measurement of lupin belowground nitrogen accumulation and recovery in the subsequent cereal-soil system in a semi-arid Mediterranean-type climate. Plant and Soil 302:297-316.

Mellado, M. 2007. El trigo en Chile. Colección libros Instituto de Investigaciones Agropecuarias (INIA) $\mathrm{N}^{\circ} 21.684$ p. INIA Quilamapu, Chillán, Chile.

Osborne, C.A., M.B. Peoples, and P.H. Janssen. 2010. Detection of a reproducible, single-member shift in soil bacterial communities exposed to low levels of hydrogen. Applied and Environmental Microbiology 76:1471-1479.

Papakosta, D.K., and A.A. Gagianas. 1991. Nitrogen and dry matter accumulation, remobilization, and losses of Mediterranean wheat during grain filling. Agronomy Journal 83:864-870.

Peoples, M.B., J. Brockwell, D.F. Herridge, I.J. Rochester, B.J.R Alves, S. Urquiaga, et al. 2009. The contributions of nitrogenfixing crop legumes to the productivity of agricultural systems Symbiosis 48:1-17.

Pierce, F.J., and C.W. Rice. 1988. Crop rotation and its impact of efficiency of water and nitrogen use. p. 101-113. In Hargrove (ed.) Cropping strategies for efficient use of water and nitrogen ASA Special Publication $\mathrm{N}^{\circ} 15$. American Society of Agronomy (ASA), Madison, Wisconsin, USA.

Raison, R.J., M.J. Connell, and P.K. Khanna. 1987. Methodology for studying fluxes of soil mineral-N in situ. Soil Biology and Biochemistry 19:521-530.

Robertson, G.P., and P. Groffman. 2007. Nitrogen transformations.p. 341-364. In E.A. Paul (ed.) Soil microbiology, biochemistry, and ecology. Springer, New York, USA.

Rochester, I.J., M.B. Peoples, N.R. Hulugalle, R.R. Gault, and G.A Constable. 2001. Using legumes to enhance nitrogen fertility and improve soil conditions in cotton cropping systems. Field Crops Research 70:27-41.

Rouanet, J.L. 1989. Rol de las leguminosas en la rotación. In Leguminosas como alternativas de rotación para la zona sur p. 3-21. In Mera, M., y E. Kehr (eds.) V Seminario Nacional de Leguminosas de Grano, Temuco. 20-21 Julio 1989. Serie Carillanca $\mathrm{N}^{\circ} 10$. Instituto de Investigaciones Agropecuarias INIA, Temuco, Chile.

Sadzawka, A., M.A. Carrasco, R. Grez, M.L. Mora, H. Flores, y A Reaman. 2006. Métodos de análisis recomendados para los suelos de Chile. Revisión 2006. Serie Actas INIA No 34. 164 p. Instituto de Investigaciones Agropecuarias INIA, Centro Regional de Investigación La Platina, Santiago, Chile.

Sarandón, S.J., S.I. Golik, y H.O. Chidichimo. 1997. Acumulación y partición del nitrógeno en dos cultivares de trigo pan ante la fertilización nitrogenada en siembra directa y convencional. Revista de la Facultad de Agronomía, La Plata 102:175-186.

Seymour, M., J.A. Kirkegaard, M.B. Peoples, P.F. White, R.J. French, and A. van Burgel. 2012. Break-crop benefits to wheat in Western Australia - insights from over three decades of research. Crop and Pasture Science 63:1-16.

Shoji, S., R. Dahlgren, and M. Nanzyo. 1993. Classification of volcanic ash soils. In Shoji, S., M. Nanzyo, and R.A. Dahlgren (eds.) Volcanic ash soils: Genesis, properties and utilization. Developments in Soil Science 21. p. 73-100. Elsevier Science Publishers, Amsterdam, The Netherlands. 
Stockdale, E.A., J.L. Graunt, and J. Vos. 1997. Soil-plant nitrogen dynamics: what concepts are required? European Journal of Agronomy 7:145-159.

Sun, M., Z. Gao, Z.P. Yang, and L.H. He. 2012. Absorption and accumulation characteristics of nitrogen in different wheat cultivars under irrigated and dryland conditions. Australian Journal of Crop Science 6:613-617.

Tottman, D.R., and R.J. Makepeace. 1979. An explanation of the decimal code for the growth stages of cereal, with illustrations. Annals of Applied Biology 93:221-234.
Urquiaga, S. 2000. Eficiencia de la fertilización nitrogenada en los principales cultivos anuales. p. 31-49. In Urquiaga, S., y F. Zapata (eds.) Manejo eficiente de la fertilización nitrogenada de cultivos anuales en América Latina y el Caribe. Empresa Brasileira de Pesquisa Agropecuária, Agrobiologia, Rio de Janeiro, Brasil.

Zagal, E., N. Rodríguez, I. Vidal, y G. Hofmann. 2003. Eficiencia de uso y dinámica del nitrógeno en una rotación con y sin uso de residuos. Agricultura Técnica 63:298-310. 